\title{
GOVERNANCE OF EXPEDITION CRUISE SHIP TOURISM IN THE ARCTIC: A COMPARISON OF THE CANADIAN AND RUSSIAN ARCTIC
}

\author{
ALBINA PASHKEVICH,* JACKIE DAWSON,† AND EMMA J. STEWART \\ *School of Technology and Business Studies, Dalarna University, Borlänge, Sweden \\ †Department of Geography, University of Ottawa, Ottawa, Canada \\ $\ddagger$ Faculty of Environment, Society and Design, Lincoln University, Lincoln, New Zealand
}

\begin{abstract}
Expedition style cruise tourism represents a significant proportion of shipping activity across the Arctic. This article compares and contrasts governance structures that manage the cruise sector from case studies located in the Canadian (Nunavut) and the Russian Arctic (Murmansk and Arkhangelsk regions). Analysis of sources, including interviews with key stakeholders, strategic tourism plans, and an inventory of institutional governance reveals that in both these locations there is no central authority to govern the growth of the industry, no specific cruise or yacht management plans, and no site guidelines for highly visited shore locations (other than in protected areas). The article concludes that under current conditions there are significant barriers to supporting development of the expedition cruise sector in both these Arctic regions.
\end{abstract}

Key words: Canadian Arctic; Russian Arctic; Expedition cruise tourism; Governance; AMSA marine navigation scenarios

\section{Introduction}

Each summer season cruise ships visit destinations that were once totally inaccessible to tourists, such as the North Pole, Northwest Passage, and the Northern Sea Route. As a result, cruise ship tourism now represents a significant proportion of the vessel activity reported in the Arctic, and the number of ships is expected to grow (Arctic Marine Shipping Assessment [AMSA], 2009; Pizzolato et al., 2013). The majority of ships are relatively small expedition style vessels that hold less than 200 people; other vessels include yachts and larger luxury cruise liners. Growth is not without concern, such as the release of oil through accidental or illegal discharge, ship strikes on marine mammals, the introduction of alien species, disruption of migratory patterns of marine mammals, and noise produced from marine shipping activity. Also of concern are the problematic ice conditions (such as the prevalence of multiyear ice) for transiting vessels as the Arctic Ocean transitions to an ice-free 
summer (Howell, Tivy, Yackel, \& McCourt, 2008). By contrast, there are positive outcomes associated with growth in the sector, such as economic development opportunities, including the promotion and access to indigenous cultures and traditions, historic and contemporary arts, and providing much needed supplementary income to remote Arctic residents (Furgal \& Prowse, 2008; Sivummut Economic Development Strategy Group [SEDSG], 2003). However, the opportunities associated with the industry will certainly be outweighed by the potential impacts if effective management and governance regimes are not in place (see Dawson, Johnston, \& Stewart, 2014).

The heaviest passenger vessel traffic is seen along the Norwegian coast, off the coast of Greenland, Iceland, and Svalbard (AMSA, 2009). Though there is passenger vessel traffic in the Canadian Arctic, the Russian Arctic, and Alaska, those numbers are relatively small in comparison to the higher traffic areas around Svalbard and Greenland. Because of the smaller historic volume of cruise activity in Canada and Russia, the regions have tended to lack robust and effective management systems. In the past, the need for strong management of the industry was not needed because the size of the industry allowed for effective self-regulation. This is now changing as more ships visit these regions, warranting focused research and policy attention (Dawson et al., 2014).

Effective governance includes regulations and infrastructure that serve to both manage and support the industry. Governance of the cruise sector varies across the Arctic (i.e., nation to nation) and there is a general lack of marine infrastructure in the region, except for areas along the Norwegian coast and northwest Russia, where compared with other marine regions of the world there are high concentrations of ship traffic (AMSA, 2009). The current lack of marine infrastructure and focused regulation, coupled with unpredictable ice conditions, makes conduct of emergency response and management and monitoring of the sector extremely challenging (AMSA, 2009).

Empirical research exploring the management of the Arctic cruise sector has almost exclusively taken a regional geographic approach, with interesting case studies emerging from locations where cruise tourism has witnessed growth: see, for example,
Headland (2010) on the North Pole; Sheppard (2010) and Ringer (2010) on Alaska; and Hull and Milne (2010) on Maritime Canada. However, it is rare that the research reported extends beyond the waters of national jurisdictions to include comparative research between different Arctic nations. Responding to the call by Lück, Maher, and Stewart (2010) for more pan-Arctic marine tourism research, this article aims to assess the capacity of existing Arctic marine regulations and governance structures to deal with the changing environmental and economic conditions affecting passenger vessel sector in two contrasting Arctic regions: the Canadian and Russian Arctic.

In this article we adopt the Arctic Marine Shipping Assessment matrix (Fig. 1) to situate our comparative study. The matrix illustrates a series of potential future shipping scenarios that were established though the Arctic Marine Shipping Assessment initiative (AMSA, 2009; also see Hodgson, 2010; Smith \& Stephenson, 2013). The scenarios focus on two main uncertainty factors thought to play major roles in the future of shipping development: governance (less stable vs. more stable) and resources and trade (more demand vs. less demand). This matrix helps to outline four potential future scenarios, including the Arctic Race (high demand and unstable governance), Arctic Saga (high demand and stable government), Polar Lows (low demand and unstable government), and Polar Preserve (low demand and stable government) (Fig. 1).

This framework provides an effective and useful foundation for comparing and contrasting Arctic cruise tourism governance in the two regions currently and also allows for commentary on how each nation might achieve their desired future state with regard to cruise ship tourism. Assuming that tourism demand for future growth in cruise sector remains strong, "Arctic Saga” is the most favored quadrant for the Arctic cruise sector, characterized by high (and healthy) demand within the context of stable and robust governance structures. As noted in Figure 1, this rate of development encompasses concern for Arctic ecosystems and cultures, which are key components of the tourism system. By contrast, the quadrant described as "Arctic Race" is the least favorable given the unstable and ad hoc governance structures and the lack of concern for equitable resource development. 


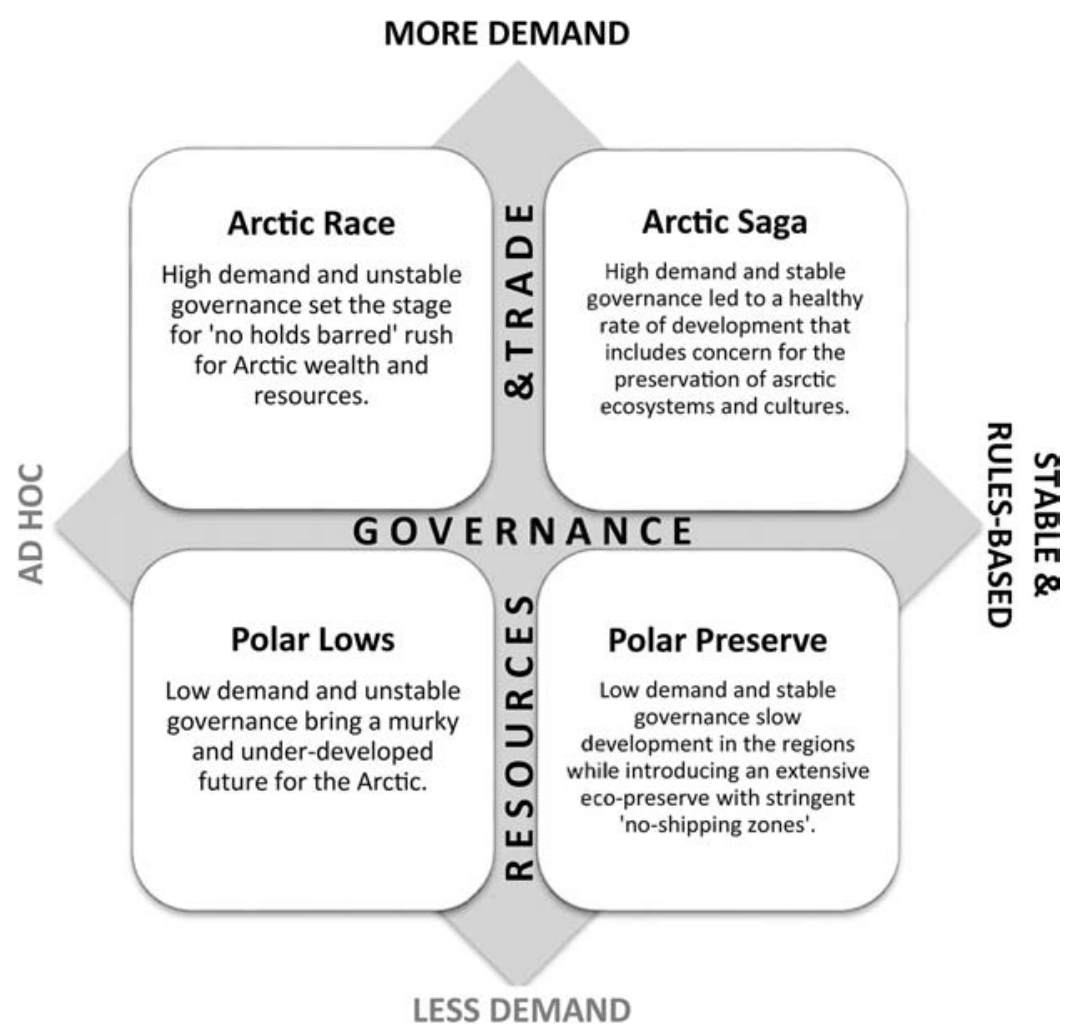

Figure 1. Arctic marine shipping assessment matrix. Source: after AMSA (2009); also see Hodgson (2010) and Smith and Stephenson (2013).

The four main objectives of the article are to: 1) identify national cruise tourism development and demand patterns; 2) provide an inventory of relevant passenger vessel policies, regulations, and institutions governing the sector; 3) highlight overlapping governance challenges; and, 4) identify recommendations for moving towards an idealized "Arctic Saga" scenario. The article outlines the methodological approaches taken, and compares and contrasts findings from both regions.

\section{Study Approach}

This study utilizes a mixed-method approach comparing and contrasting a variety of data sources from both case study locations. Content analysis of the extensive data collected from published and electronic sources (Hall \& Valentin, 2005) is coupled with the primary data obtained mainly by using semistructured interviews with key stakeholders in both regions. Primary data for the Canadian case study was collected through the multiyear research project, “Cruise Tourism in Arctic Canada” (CTAC), which began in 2009 (CTAC, 2013). Systematic web-based searches of itineraries offered by expedition cruise operators to Canada were conducted annually between 2006 and 2014 and were compared to the only other source of ship track information available in Arctic Canada, the Canadian Coast Guard's NORDREG (northern Canada vessel traffic monitoring services) annual datasets. Governance challenges and potential adaptation strategies and policy alternatives were synthesized through various sources of information including material from almost 500 interviews with residents of Arctic communities, cruise ship operators, and policy stakeholders, as well as from a series of workshops, round table exercises, extensive document review, and rudimentary examination of other national passenger vessel management regimes. 
All of the collected data were coded thematically, categorized, and compared with additional data as they were generated (see Dawson et al., 2014).

Similarly, the Russian case study was initiated in 2011 through a research project called "From Resource Hinterland to Global Pleasure Periphery?” (Mistra Arctic Futures, 2014). Interviews and on-site observations with more than 40 key stakeholders dealing both directly and indirectly with tourism development planning and management in Murmansk and Arkhangelsk regions were combined with information gathered from the series of conferences, seminars, workshops, and round table events. Additional information concerning up-todate policy documents, state of the development of marine infrastructures, examination of traffic volumes, and current problems were obtained through web searches from official governmental and thematic websites available predominantly in Russian. The data were transcribed into English, thematically categorized, and compared with the Canadian case study. The information concerning governance in the two case study locations was organized according to their transnational, national, or regional/local scale. Following the AMSA framework, the information under these broad spatial categories was analyzed and main challenges were identified for both case studies.

\section{Cruise Tourism Development in Arctic Canada and Northwest Russia}

The Canadian Arctic Archipelago stretches longitudinally about $1,900 \mathrm{~km}$ from mainland Canada to the northern tip of Ellesmere Island (Fig. 2). The region covers a distance of about 2,400 km from Banks Island in the west to Baffin Island in the east. The region comprises approximately 36,000 islands, and is sparsely populated by largely Inuit communities, making it one of the most complex coastlines on Earth. There are five recognized routes or passages, with variations, through the Archipelago, which comprise the fabled Northwest Passage (the name given to the various marine routes between the Atlantic and Pacific oceans along the northern coast of Canada) that occupied European adventurers for more than 400 years.

The MS Explorer made the first transit of the Northwest Passage in 1984 (Jones, 1999; Marsh \&
Staple, 1995), illustrating that the Canadian Arctic is a late-comer to cruise tourism partly because of the prevalence of ice-infested waterways up until relatively recent times. Since the mid-1980s a sporadic, but increasingly regular, pattern of cruise activity emerged across the region, and not just limited to the Northwest Passage (Maher \& Meade, 2008; Stewart, Dawson, \& Draper, 2010), with 2006 identified as a watershed season, when the number of cruises doubled (Buhasz, 2006). Growth continued and peaked in 2010 (with 26 cruises); however, the lingering influence of the global economic crisis and several major business decisions meant a drop in cruises from 2010 onwards (Quinn, 2012). A rebound in vessel numbers occurred during the 2013 and 2014 seasons throughout the region.

In general, the operating season is short-from late July to mid-October-depending on the route and year. Despite some challenging sea ice conditions, cruise operators in the region have a relatively good human and environmental safety record (Stewart \& Dawson, 2011). However, cruising in the region has not been without incident; for example, in 1996 the Hanseatic grounded off Cambridge Bay and in the summer of 2010 the Clipper Adventurer also grounded, necessitating icebreaker assistance (Stewart \& Dawson, 2011). Smaller vessels have also caused concerns such as illegal entry, carrying illegal fireworks, alcohol violations, and disturbance to wildlife (George, 2012; M. Johnston, Dawson, Stewart, \& De Souza, 2013).

According to AMSA (2009), "destinational" shipping is anticipated to increase in the Canadian Arctic, partly driven by increasing cruise tourism. The changing climate will result in increased accessibility and a longer shipping season, which will in turn also affect future activity levels. While the summer climate in the Canadian Arctic region is changing, ice will be present during most of the year, meaning that access to the Northwest Passage will continue to be controlled by ice conditions. Despite widespread speculation, the uncertainty of conditions in the Northwest Passage due to seasonal variability, changing ice conditions, and so forth indicate that operational costs will continue to be high in the future (AMSA, 2009).

The total size of the continental Russian Arctic consists of 3.7 million $\mathrm{km}$ or almost $22 \%$ of the total Russia's territory. By contrast to the small 

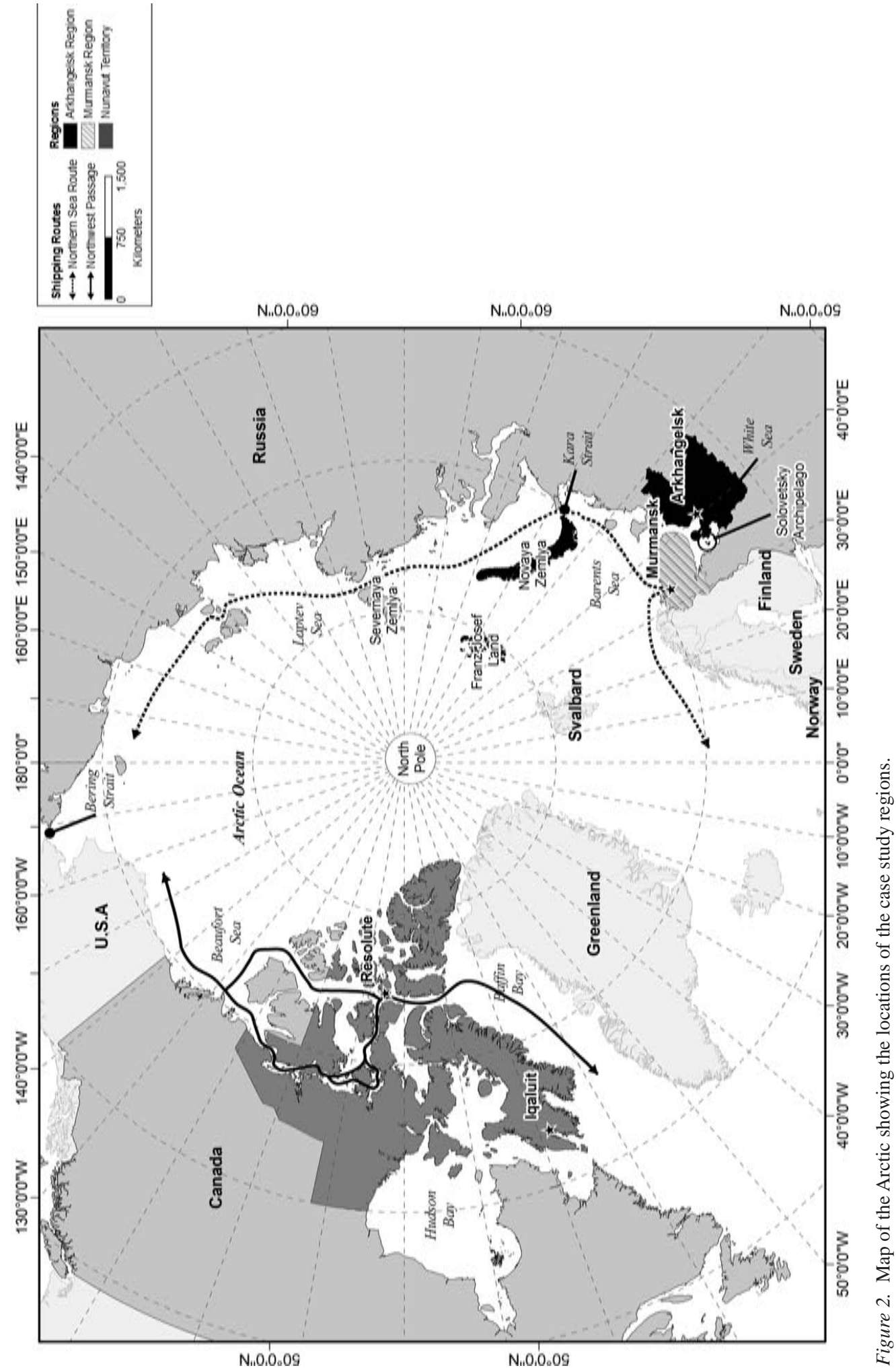
population of Arctic Canada, there are 2.3 million inhabitants in the Russian Arctic region, including some 150,000-250,000 inhabitants belonging to native indigenous groups. The northwestern part of the Russian Arctic studied in this article comprises the Barents Sea area with approximately 824,000 km (Stephenson, Brigham, \& Smith, 2014), in addition to some 95,000 km of the White Sea area. This part of Russian Arctic [western region of the Northern Sea Route (NSR)] represents the most intensive transportation system in the region, including yearround natural resource transportation (Stephenson et al., 2014). Compared with the Canadian Arctic, the Russian maritime Arctic has more viable ports located along the length of the NSR; as a result, significant infrastructure investments that have been made in the region in recent years. However, the physical environment of the Russian Arctic also presents challenges particularly due to the shallow waters that generally characterize the length of the coastline from the Norwegian-Russian border in the west (in the Barents Sea) to the Bering Strait. As in the Canadian Arctic, cruise ships and smaller cargo vessels only operate in the summer months with the navigation season extending from July to October.

The period from 1930 to 1935 is often considered to be the starting point for the exploration efforts of the Soviet state in the western region of the NSR. However, it was not until 2003 when the area was first visited by the cruise ship, the MS Explorer, making another inaugural voyage. Since that first voyage, the overall number of foreign cruise vessels visiting Arkhangelsk region until 2013 was 27 (Agency of Tourism and International Cooperation [ATIC], 2013). The Murmansk region followed a similar trend as experienced in Canada, beginning with between three and six vessels in the early 2000s, with the peak in 2012 with 15 cruise vessels entering the port of Murmansk, and mainly destined for the return visit to the North Pole via several islands of the archipelago Franz Josef Land (Pashkevich \& Stjernström, 2014). Another popular destination after Murmansk is towards the White Sea and the port of Arkhangelsk and a group of islands of Solovetsky archipelago and back to Murmansk. Large liners that have to date not attempted to visit Canadian Arctic waters, such as the Ocean Princess (with 830 passengers), have also visited
Murmansk. Until the construction of the new passenger port facilities (planned to open in 2016) the ships arrive into the fishing port.

According to AMSA (2009), increased marine traffic in the Russian Arctic is a "reality for scientific exploration and tourism” (p. 121). The future holds increasing exploration voyages, plausible increases in tourism, fishing, and trans-Arctic voyages in summer. As in Canada, voyages to the Russian Arctic in the future will be overwhelmingly destinational driven by natural resource development, marine tourism, and supply/import of materials/goods.

Current mechanisms for governing passenger vessels in the Canadian Arctic and Northwest Russia are explored in the following section.

\section{Governance Mechanisms for Cruise Vessels in Arctic Canada and Northwest Russia}

The passenger vessel sector in the Canadian and Russian Arctic is based on the "expedition" model of polar cruising (A. Johnston, Johnston, Dawson, \& Stewart, 2012; A. Johnston, Johnston, Stewart, Dawson, \& Lemelin, 2012; Pashkevich \& Stjernström, 2014; Stewart et al., 2010). Unlike industrial shipping, these vessels transport fare-paying passengers to view landscapes at close range, so that they may experience the Arctic first hand. This involves accessing shore locations, seeking out wildlife viewing opportunities, visiting local communities and interacting with local people, and venturing into new, different, or challenging and sometimes uncharted waters. So while many of the issues of passenger vessel ships are similar to industrial shipping and bulk marine transportation-for which existing regulatory frameworks have been established-there are important differences that dictate the need for a more focused sector-specific management regime (Dawson et al., 2014).

The expedition cruise sector in both regions is largely governed by a set of complex international conventions, laws, and regulations that apply across all types of shipping in the Arctic regions (Dawson et al., 2014). There are four international maritime conventions that form a foundation for multinational maritime governance: 1) the International Convention for Safety of Life at Sea (SOLAS), 2) the International Convention for the Prevention of 
Pollution from Ships (MARPOL), 3) the Convention on Standards of Training of Seafarers (STCW), and 4) the United Nations Convention on the Law of the Sea (UNCLOS). The latter provides a fundamental legal framework for the governance of Arctic marine navigation and allows coastal states the right to adopt and enforce nondiscriminatory laws and regulations for the prevention, reduction, and control of marine pollution from vessels in ice-covered waters (Article 234). The International Maritime Organization (IMO) has been proactive in developing voluntary Guidelines for Ships Operating in Arctic Ice-covered Waters, which continue to evolve. There are no uniform, international standards for ice navigators and for Arctic safety and survival for seafarers in polar conditions. And there are no specifically tailored, mandatory environmental standards developed by IMO for vessels operating in Arctic waters (AMSA, 2009). The IMO is currently developing a draft of the Polar Code, an international code of safety for ships operating in polar waters (i.e., both in the Arctic and the Antarctic), which considers the full range of design, construction, equipment, operational, training, search and rescue, and environmental protection matters relevant to all ships operating in polar waters (IMO, 2014). Recently, IMO’s Maritime Safety Committee (MSC) has, in principle, approved the Polar Code draft and the related amendments to make the Code mandatory under SOLAS. The plan is to get it formally adopted at the next session in November 2014. However, the adoption of these regulations is not binding and depends on a goodwill of each country operating in the area. The work on passenger vessel safety and regulation will continue (Association of Arctic Expedition Cruise Operators [AECO], 2014a).

Similar to the Antarctic's self-regulatory International Association of Antarctica Tour Operators (IAATO), the Arctic regions have the Association of Arctic Expedition Cruise Operators (AECO), which is an international association for expedition cruise operators operating in the Arctic (AECO, 2013). Founded a decade or so later than IAATO, AECO (founded in 2003) represents the concerns and views of Arctic expedition cruise operators, and is dedicated to managing responsible, environmentally friendly, and safe tourism in the Arctic as well as setting the highest possible operating standards. The association's geographical range is considered to encompass the Arctic area north of $60^{\circ}$. The core areas are Svalbard, Jan Mayen, Greenland, and the national park "Russian Arctic" (AECO, 2014a). Arctic Canada was included under AECO’s jurisdiction in 2014. AECO has approximately 40 international companies that operate almost 30 vessels in Svalbard, Greenland, Canada, and the Russian Arctic. However, there are hundreds of vessels operating in these regions, meaning that AECO currently only captures a small percentage of them. Membership to AECO is voluntary and members incur an annual membership fee. Many operators do not see the full benefits of being part of AECO, which limits the organization's ability to govern and support industry growth and development.

In addition to the overarching framework provided by the IMO and sector-specific, but noncomprehensive, support provided by AECO, there are additional mechanisms determined at the country level, which are relevant for cruise ships operating in Polar waters. In Canada, relevant mechanisms include: the Oceans Act, the Arctic Waters Pollution Prevention Act (AWPPA), the Canada Shipping Act (CSA), the Marine Liability Act (MLA), the Marine Transportation Security Act (MTSA), the Navigable Waters Protection Act (NWPA), and the Coasting Trade Act (CTA). As reported in Dawson et al. (2014), Figure 3 outlines a variety of federal, territorial, and local-level institutions involved in supporting the passenger vessel sector not only through the administration of federal acts. But again, the vast majority of these frameworks oversee all shipping in Arctic Canada and have not been established to support or manage the cruise sector specifically. As a result, there is a very complex permitting process required for operation of any passenger vessel in Arctic Canada. The process is extensive and requires operators to contact over 30 federal, territorial, and local-level agencies to obtain the necessary licenses, permits, and informal permissions for operation (Fig. 3).

Similarly, the number of official controlling authorities involved in cruise tourism development in Russia has risen to more than 30 and continues to grow (Fig. 4). Russia complies with the guidelines provided by IMO as the basis for decision 


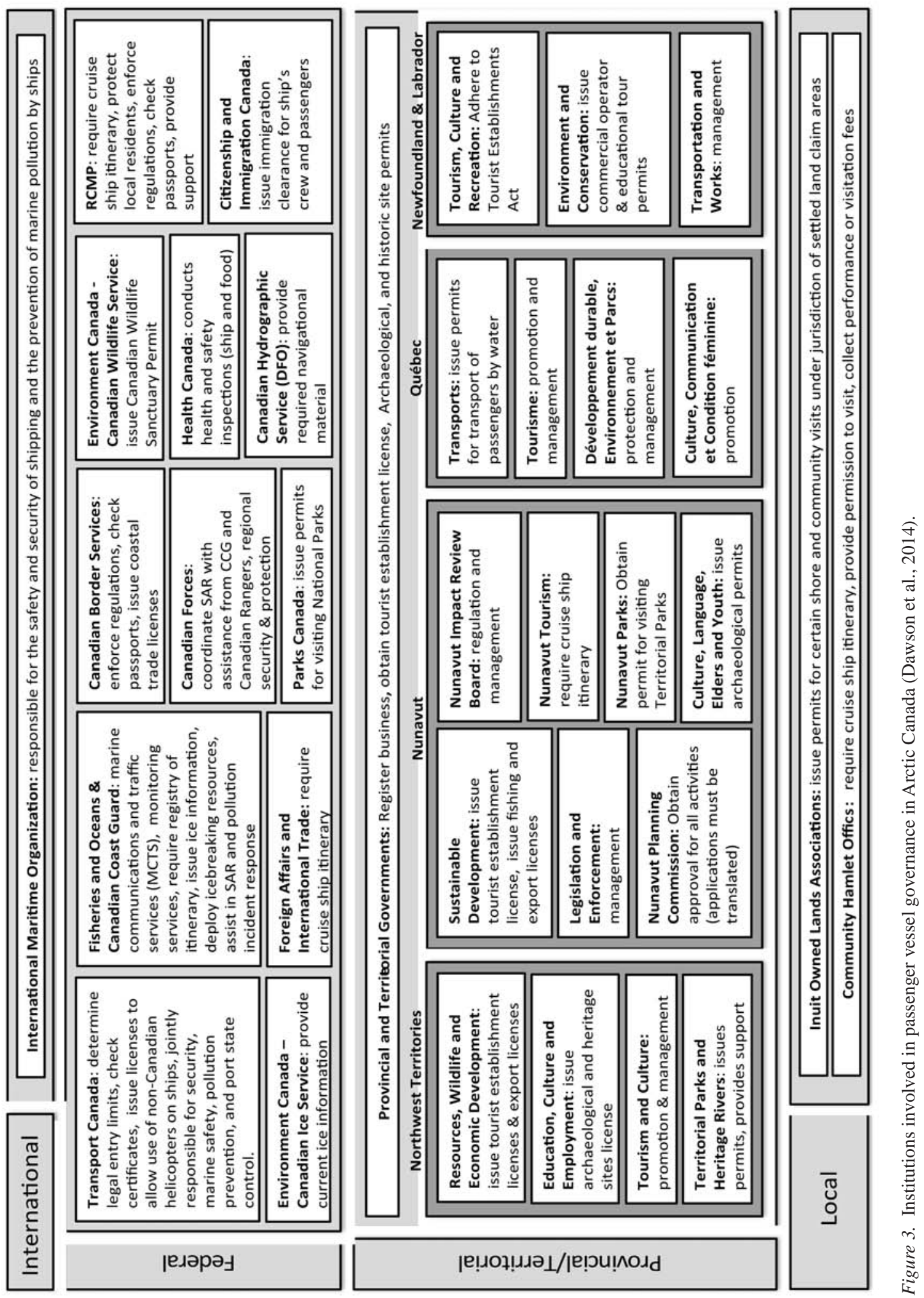



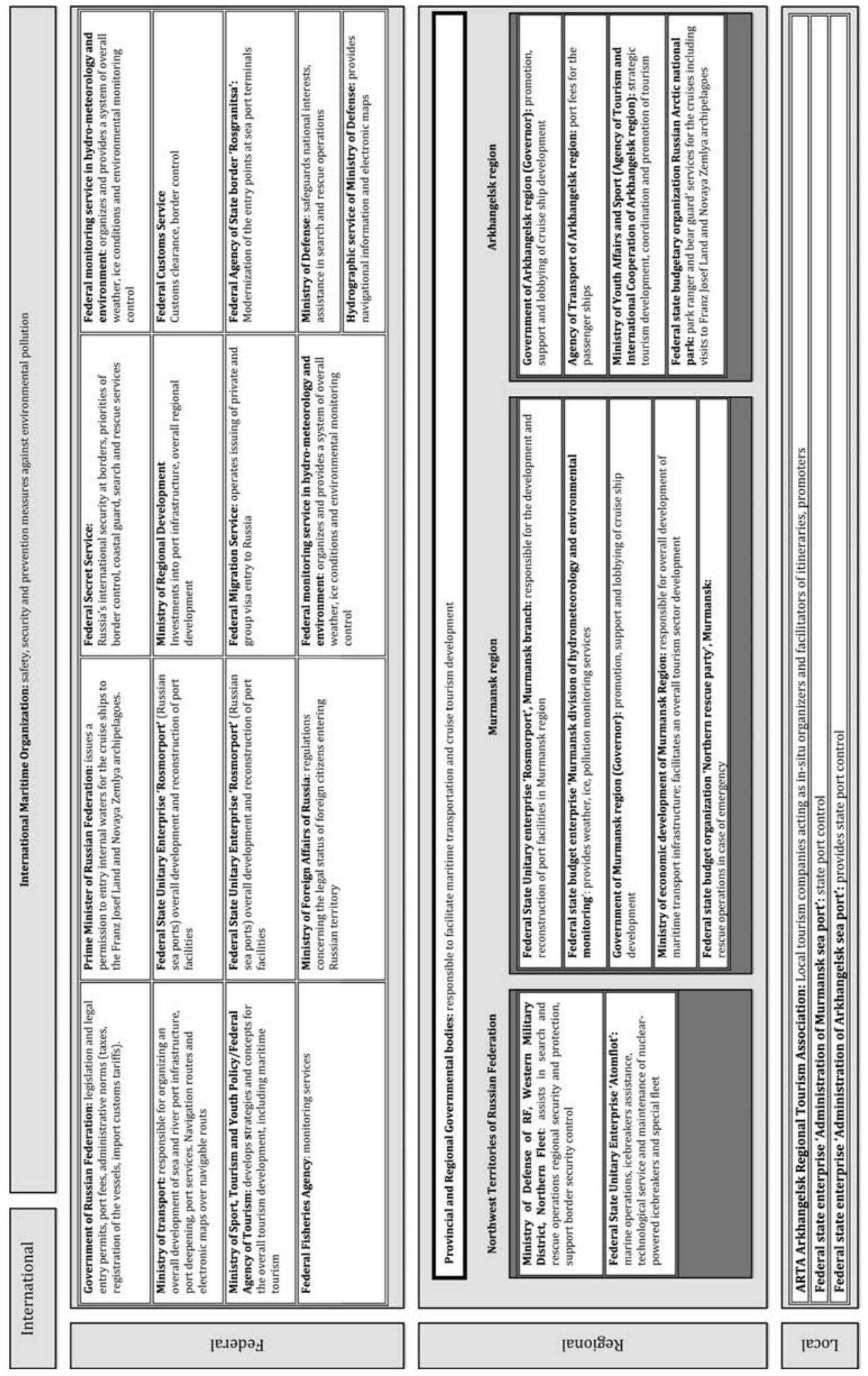

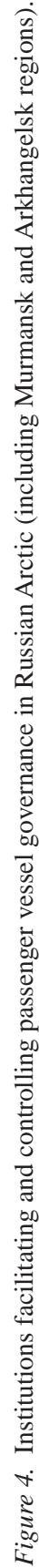


making concerning the passenger vessel operations in the Russian Arctic. The Russian Maritime Security Service is responsible for implementation of Russia's national security requirements and controls for the ratification of International Maritime Safety Agreements and Instruments. According to AMSA (2009), the Russian Federation lies ahead of Canada in terms of the ratification of International Maritime Safety Agreements. As Figure 4 illustrates, institutional arrangements at both federal and regional level that are responsible for permitting, controlling, and facilitating cruise ship traffic in the Arctic waters are even more complex compared to the Canadian situation. The number of controlling authorities creates inconsistencies in the application of rules and standards, especially on a regional basis, and in many cases it slows down their implementation in practice (Aleksandrov, 2012).

In both the Canadian and Russian case studies it appears that governing of the cruise ship sector is overly complex and completely inefficient. There are multiple institutions operating at different scales with overlapping responsibilities. This situation undermines the development of the sector; for example, foreign operators bringing tourists into Russia rely on a long history of established connections and intermediaries in Russia, which is necessary in order to navigate unpredictable decision-making processes. In the Russian case the issues connected to the entry visa permits and getting access to the more remote Arctic archipelagoes is still overly complicated and decisions are taken on the level of Russian Prime Minister, which slows down the entry process considerably. In comparison to the Canadian case, the question of the environmental impacts of the tourism activity in the Arctic is only in the early stage of assessment. The system for this type of control is still not in place and priority is given to Russia's national security and border control with eight different governmental organizations controlling the process. The development of the tourism sector in the Russian case is still carried out in a top-down manner with the central and regional government offices being responsible for its development. The Canadian case shows a clear division of power in this case, with the priorities given towards federal and regional authorities that do not efficiently communicate, leaving limited control or decision making with local communities where impacts and benefits are actually felt the strongest.

\section{Governance Challenges for the Management of Cruise Tourism in Arctic Canada and Northwest Russia}

Now that the existing governance framework for the cruise sector in both case study locations has been introduced, the article turns to an analysis largely based on the interview and workshop portions of the Canadian and Russian studies, of challenges that currently constrain effectual governance of the cruise industry (Table 1). Notable governance challenges, which cut across both the Canadian and Russian Arctic, are elaborated upon.

At the international scale, since passenger vessels move between jurisdictions, both national and international, they are subject to each jurisdiction's set of regulatory systems as well as to the registry guidelines associated with the county in which the vessel is registered. Open registry shipping is typical of passenger vessels and is often advantageous because the popular countries for registration (e.g., Bahamas, Panama, Cook Islands) usually have "less stringent safety, labour and environmental regulations than do the countries of destination" (Dawson et al., 2014, p. 91). One of the main disadvantages to this system is the potential for an increase in security threats that could range from minor drug or liquor violations to major issues such as human trafficking. The potential for regional- and local-scale security risks in Canada are thought to be increasing, considering the absence of comprehensive Arctic patrols, the limited resources of the Coast Guards, the remote and geographically large area requiring surveillance, and the increasing number of vessels traveling through the region annually.

In Russia, potential security threats are prevented by the legislative system restricting access to the internal waters of the Arctic regions. Over recent years Russia has demonstrated growing presence in the area, particularly with regard to natural resource extraction in the region. The increased military presence in the Barents Sea area and the reestablishment of old military bases along the NSR are signs of Russia strengthening its national interests. Consequently, increased use and military presence, potential security risks, such as smuggling and 
Table 1

Summary of the Governance Challenges Identified in the Canadian and Russian Case Study

\begin{tabular}{|c|c|c|c|}
\hline Scale & $\begin{array}{l}\text { Governance } \\
\text { Challenge }\end{array}$ & Canada & Russia \\
\hline \multirow[t]{2}{*}{ International } & $\begin{array}{l}\text { Transnational } \\
\text { operating } \\
\text { context }\end{array}$ & $\begin{array}{l}\text { Prevalence of foreign-flagged } \\
\text { vessels, and likely impacts }\end{array}$ & $\begin{array}{l}\text { Foreign-flagged vessels dominate; } \\
\text { Russian vessels are present but hired } \\
\text { by foreign companies to carry out } \\
\text { passenger cruises; North Pole cruises } \\
\text { on board of the Russian atomic } \\
\text { icebreakers }\end{array}$ \\
\hline & $\begin{array}{l}\text { Risk to national } \\
\text { security }\end{array}$ & Security risks already identified & $\begin{array}{l}\text { Still very unclear situation with the } \\
\text { several authorities controlling this } \\
\text { process and overlapping their duties }\end{array}$ \\
\hline \multirow[t]{3}{*}{ National } & $\begin{array}{l}\text { Immigration } \\
\text { processes }\end{array}$ & $\begin{array}{l}\text { Expensive process in place; } \\
\text { becoming more streamlined }\end{array}$ & $\begin{array}{l}\text { Unpredictable; variance in rules } \\
\text { applied in different ports }\end{array}$ \\
\hline & $\begin{array}{l}\text { Increase in } \\
\text { other maritime } \\
\text { activities }\end{array}$ & $\begin{array}{l}\text { Waterways becoming } \\
\text { increasingly busy }\end{array}$ & $\begin{array}{l}\text { Icebreaker support needed for non- } \\
\text { tourism-related activity; link to } \\
\text { proposed halt to North Pole oper- } \\
\text { ations in } 2015\end{array}$ \\
\hline & $\begin{array}{l}\text { Search and } \\
\text { Rescue }\end{array}$ & $\begin{array}{l}\text { Rescue coordination; numerous } \\
\text { examples of incidents }\end{array}$ & $\begin{array}{l}\text { Linked to North Sea Route Russian } \\
\text { authorities plan a comprehensive } \\
\text { system of SAR; examples of nuclear } \\
\text { submarines role in rescues }\end{array}$ \\
\hline \multirow[t]{4}{*}{ Regional/Local } & $\begin{array}{l}\text { Insufficient } \\
\text { infrastructure }\end{array}$ & $\begin{array}{l}\text { Tourism and maritime facilities } \\
\text { are limited }\end{array}$ & Absence of proper port facilities \\
\hline & & Aging fleet of vessels & $\begin{array}{l}\text { Aging fleet requires more labour } \\
\text { on board }\end{array}$ \\
\hline & $\begin{array}{l}\text { Unique } \\
\text { challenges of } \\
\text { expedition } \\
\text { style cruising }\end{array}$ & $\begin{array}{l}\text { Increasing numbers of shore } \\
\text { locations being explored; } \\
\text { alongside concentration } \\
\text { of “must see” honey pot } \\
\text { locations especially through } \\
\text { the Northwest Passage. } \\
\text { Multiple visits in one day }\end{array}$ & $\begin{array}{l}\text { Landings are more complex than for } \\
\text { larger liners; presents problems for } \\
\text { management }\end{array}$ \\
\hline & Site guidelines & $\begin{array}{l}\text { Lacking up until now (Parks } \\
\text { Canada sites), but likely to } \\
\text { change with advent of AECO }\end{array}$ & $\begin{array}{l}\text { Pockets of control such as those set by } \\
\text { Ministry of Natural Resources \& } \\
\text { Environment for national park's visits, } \\
\text { but complete absence of guidelines for } \\
\text { the territories outside specifically } \\
\text { protected areas }\end{array}$ \\
\hline
\end{tabular}

human trafficking, presented by the cruise industry are thought to be minimized in the area.

High port charges and the absence of proper passenger port facilities are other factors that both limit and challenge the further development and investments in cruise ship development in Russia. At the same time the regulatory system and the priorities for the development of the Russian Arctic have been clearly stated by President Medvedev from 2009 onwards ("Main Principles of State Policy," 2009). The ability to develop cruise ship tourism is strongly correlated with the political decisions behind the allocations of funds towards improvements of the transport infrastructure of the remote Russian regions.
Furthermore, shared responsibilities concerning various aspects of the management of cruise tourism lead to the development of large-scale constellations suitable for cruise vessels carrying more than 600 passengers in established ports along the Arctic coast (e.g., Murmansk and Arkhangelsk). The control over the operations performed within the expedition-type landings is much more complicated for the authorities and as a result the necessary flexibility and issues of trust are still not fully developed. It is felt more practical to create a few entry points, allowing greater control over tourism operations. This situation further illustrates that the institutional arrangements surrounding cruise travel are unnecessarily complicated. 
At the local level, there are significant capacity and infrastructure deficits across both Arctic Canada and Russia. Compared to most other Arctic regions attracting passenger vessel activity, Canada's and Russia's tourism infrastructure and local services are minimal. For example, in the Canadian Arctic there are no public use deep-water ports, refueling stations, or reliable resupply locations; the communications infrastructure and search and rescue services are extremely limited; and there is a lack of tourism services and human resources (Dawson et al., 2014). Promises have been made to procure "off-shore patrol vessels," improve communications infrastructure, port infrastructure, and monitoring capacity in Canada. But these deficit areas create barriers to successful economic development, and only exacerbate risks associated with safety, security, and environmental sustainability. Without improved capacity, these infrastructure limitations are serious, leading many Canadian policy makers in the region (echoing concerns from elsewhere in the Polar Regions) to believe "it is only a matter of time before we witness a major ship based accident in Arctic Canada" and it has been stated that "the worst possible Arctic shipping accident at this time would be a passenger vessel sinking."

Furthermore, infrastructure along the Russian Arctic coast is still unable to support any potential increases in volumes of passenger traffic and safety transportation. The control over the waterways and port facilities is divided among the numerous state and non-state actors, which complicates the situation of safety control and overall maintenance of the port passenger facilities. The Russian organization "Atomflot" currently operating the North Pole cruises announced that after the year 2015 it will stop running these cruises. The increased volumes of traffic along the NSR and the mandatory icebreaker escort for all shipping along the route demands the availability of the icebreaker fleet supporting navigation along the NSR.

Another concern highlighted in both Canada and Russia is the advanced age of the passenger vessels that are currently operating, many of which are now functioning well beyond their estimated "service life" and as a result have a higher potential for failure. Of the passenger vessels regularly operating in Canadian Arctic waters, over one half are overdue for refurbishing and by 2020 this will increase to all but one (Brosnan, 2011). Similarly, Russia owns four atomic icebreakers for use by the cruise industry, but by 2021 only one will be operational (50 Years of Victory). It is essential to develop a modern cruise ship fleet as more than $60 \%$ of Russian domestic cruise ships and scientific vessels today are over 30 years old; that is why the Russian government is subsidizing the construction of two new icebreakers by 2018 (Egorov, 2013). Several modern Russian-flagged vessels originally built for maritime scientific investigations (such as Akademik Ioffe and Akademic Vavilov) are used today to carry on passenger cruises in the Arctic (connecting Svalbard, Greenland, and Arctic Canada), as well as Antarctic cruises.

With regard to "search and rescue" (SAR) activity, Russia is currently setting up a comprehensive system of search and rescue operations supervised by the Ministry of Transport connected primarily to the NSR. Marine rescue coordination centers operating on the territory of the Northwestern part of Russian Arctic are located in Murmansk, Arkhangelsk, and Naryan-Mar that are able to provide support if necessary. Furthermore, due to the presence of the Russian Navy's Northern Fleet in Murmansk, the waters of the Barents and White Sea are controlled by the submarines and modern patrol boats performing their combat training. In recent years, these nuclear submarines have been involved in the rescue of two Russian crews of smaller boats in distress.

By contrast, in Arctic Canada, it has become important that cruise operators themselves have their own SAR strategy in the event of an accident or incident. This is because the closest rescue coordination centers servicing the Canadian Arctic are in Halifax, Trenton, and Victoria, often meaning an 11-hour commute time to northern locations from these southern-based coordination centers (Canadian Coast Guard [CCG], 2014). However, even if rescue centers were strategically located in the north as has been suggested by many proponents, monitoring and serving the Canadian Arctic will remain extremely challenging simply due to the geographic extent, nature of the landscapes, remoteness of the region, and the fact that a large portion of the Canadian Arctic remains uncharted or poorly charted (Dawson et al., 2014).

It is also clear from this analysis that there is no central authority to govern the cruise sector in either 
Canada or Russia. This situation creates barriers for the further development of sector-specific development strategies, management plans, and operational guidelines at the regional level. Consequently, there are no specific management plans or site guidelines for highly visited shore locations (other than generic guidelines already in place for protected areas). If Canada is to encourage the development of the cruise sector in the Arctic, then it is vital that a harmonized policy framework is established to ensure environmental and human risk is minimized and economic and cultural opportunities are maximized. In the Russian case, the further development of cruise ship industry is further complicated by the presence of strong oil and gas monopolies and a volatile geopolitical situation. The decisions governing the cruise tourism sector are very closely tied to the political situation in Moscow. Unless regional and local governments are able to gain further control over operations, the sound development of cruise sector in the northwestern part of Arctic Russia is questionable. Russia appears to focus more on the exploitation of the natural resource wealth of the area rather than to ease the barriers facing the successful development of cruise tourism in the Russian Arctic. While this is not yet the case in the Canadian Arctic, the system in place in Russia is mostly targeting transhipment along the NSR and internal transportation along the Arctic coast, rather than supporting the cruise sector. Some of these issues could in part be overcome through a more comprehensive membership within AECO. However, without federal and regional government support even this would not be sufficient.

\section{Conclusion: An Arctic Race or an Arctic Saga?}

As AMSA (2009) identified, there is a "dearth of mandatory international standards specifically designed for navigation in the Arctic, as well as voluntary guidelines” (p. 67). Our findings from Canada and Russia confirm AMSA's (2009) assessment. We argue that the governance structures that have evolved to date in both the Canadian and Russian case studies indicate that the least preferred state of the "Arctic Race" is more likely to materialize in the future should the current challenges of these governance structures remain unresolved. Under current conditions the existing management system for passenger vessel governance could be described as "ad hoc" and characterized by institutional complexity, capacity deficits, and an absence of a dedicated authority to oversee management and development of guidelines and best practices. Governance of the sector occurs within the complex multijurisdictional regulatory frameworks that exist for all shipping in the region, a problematic situation considering the particular operating environment of passenger vessels that regularly travel away from main shipping corridors in search of ice, wildlife, and culture.

AMSA (2009) indicated that "Arctic states will need to work closely with global and regional international organizations, the people of the North and the international maritime community in regimebuilding to facilitate governance of Arctic shipping” (p. 67). Five years on, it appears that there are signs that an "Arctic Race" scenario can be averted for the Arctic cruise sector by greater panArctic collaboration and governance through the final mandating of the Polar Code and the sectorspecific work of AECO. These transpolar initiatives promote the need for a more stable and robust governance structure and a more harmonized regulatory framework for the Arctic cruise sector. These conditions characterize the most favorable quadrant of AMSA's (2009) “Arctic Saga” scenario, and cautiously we suggest that this situation bodes well for the future of Arctic cruising.

For the first time in the history of polar shipping, the Polar Code will help to establish synergistic regulations, providing a consistent and robust set of policies that harmonize environmental protocols, operating rules, and cooperative service arrangements across the Polar Regions (IMO, 2014; Kaltenstein, 2011). The Polar Code is intended to cover the full range of shipping-related matters relevant to navigation in waters surrounding the two poles: ship design, construction, and equipment; operational and training concerns; search and rescue; and, equally important, the protection of the unique environment and ecosystems of the polar regions (IMO, 2014).

The work of AECO, which now extends to the Canadian Arctic, also bodes well on a number of fronts for the cruise sector. For example, in an attempt to remedy what AECO call a "cumbersome, expensive and problematic” permitting system for cruise vessels in Canada, they recently sent an open letter to Canadian stakeholders involved 
with permitting requirements for expedition cruise operators or involved with the political framework behind such requirements, highlighting that improved cooperation of the Canadian authorities, and streamlining of the permitting process is needed to make tourism in this region viable. Such dialogue is important for promoting the need for a central permitting body or office, via a one-window system (AECO, 2014b; Dawson et al., 2014). Similarly, site guidelines, which already exist for some other remote Polar Regions that are popular for passenger vessels including Antarctica (Secretariat of the Antarctic Treaty, 2013) and Svalbard (AECO, 2013), are under development by AECO in partnership with university researchers and Canadian government departments. It is clear that the role of organizations like AECO should not be underestimated, as they act as agents of change and spread knowledge on best practices across the Arctic, specifically in relation to cruise ship tourism. The Arctic Council initiative to establish pan-Arctic "best practices" for cruise ships is another important example of a much-needed focus on this sector.

A more effective governance structure for the evolving passenger vessel sector in the Arctic is vital in order to regulate and support emerging economic (local and national) and sovereignty-related opportunities, but also to mitigate against negative issues associated with security and sustainability (AMSA, 2009). The two Arctic case studies presented in this article indicate that while there are many governance challenges that lie ahead, the foundations of an "Arctic Saga" future scenario have been established through the harmonizing potential of the soon-to-be ratified Polar Code, and the recently extended jurisdiction of AECO.

\section{Acknowledgments}

Appreciation is extended to residents, decision makers, and stakeholders in both the Canadian and Russian Arctic regions who contributed to the work presented in this article. The authors gratefully acknowledge support from the Social Sciences and Humanities Research Council of Canada and the Swedish Foundation for Strategic Environmental Research. We would also like to acknowledge Larissa Pizzolato at the University of Ottawa for her fine cartographic work in creating the map used.

\section{Biographical Notes}

Albina Pashkevich is a senior lecturer in Human Geography at School of Technology and Business Studies, Dalarna University, Sweden. Her research interest include investigations concerning tourism development of Arctic Russian territories, study of institutional settings allowing for the alternative development of local communities, including maritime and coastal tourism based on the cultural and natural heritage of these areas.

Jackie Dawson is the Canada Research Chair in Environment, Society and Policy and is an Assistant Professor in Geography at the University of Ottawa. Her research on the human and policy dimensions of environmental change focus on climate change impacts, vulnerability, adaptation, economic development, shipping trends, and marine governance. She works closely with coastal communities in Arctic Canada affected by changing environmental and economic conditions.

Emma J. Stewart is a senior lecturer in Parks and Tourism at Lincoln University, New Zealand as well as a Research Associate at the Arctic Institute of North America at the University of Calgary, Canada. Her research interests include human dimensions of climate change, polar tourism, cruise tourism, environmental interpretation, and community-based research approaches.

\section{References}

Agency of Tourism and International Cooperation. (2013). Perspectives of development of the cruise ship tourism in Arkhangelsk region. Retrieved May 21, 2014, from http://www.dvinaland.ru/prcenter/release/34313/

Aleksandrov, O. (2012, September 11). Strong and weak sides of Russia's Arctic strategy. MGIMO. Retrieved August 12, 2014, from http://www.mgimo.ru/news/experts/ document226687.phtml

Arctic Marine Shipping Assessment. (2009). Arctic marine shipping assessment 2009 report. Retrieved June 22, 2011, from http://www.pame.is/index.php/projects/arcticmarine-shipping/amsa

Association of Arctic Expedition Cruise Operators. (2013). AECO. Retrieved May 15, 2014, from http://www.aeco.no/

Association of Arctic Expedition Cruise Operators. (2014a). About us. Retrieved August 8, 2014, from http://www. aeco.no/about-aeco/

Association of Arctic Expedition Cruise Operators. (2014b). Canadian cruise requirements are out of control. Retrieved August 8, 2014, from http://www.aeco.no/ 2014/07/canadian-cruise-requirements-are-out-ofcontrol-2/

Brosnan, I. (2011). The diminishing age gap between polar cruisers and their ships: A new reason to codify the IMO Guidelines for ships operating in polar waters and make them mandatory? Marine Policy, 35(2), 261-265. 
Buhasz, L. (2006, July 1). Northern underexposure. Globe \& Mail. Retrieved April 14, 2014, from http://www. theglobeandmail.com/life/northern-underexposure/ article712384/?page=all

Canadian Coast Guard. (2014). Maritime search and rescue in Canada. Retrieved March 19, 2014, from http://www. ccg-gcc.gc.ca/eng/CCG/SAR_Maritime_Sar

Cruise Tourism in Arctic Canada. (2013). Summary report of potential adaptation strategies. Retrieved from http://www.arctictourismandclimate.lakeheadu.ca/sites/ default/files/Adaptation-Strategies_CTAC_6_FINAL_ citation-corrected.pdf

Dawson, J., Johnston, M., \& Stewart, E. (2014). Governance of Arctic expedition cruise ships in a time of rapid environmental and economic change. Ocean \& Coastal Management, 89, 88-99.

Egorov, G. (2013). Perspectives of development of river cruises in Russia. Morskiye vesti Rossii, 13. Retrieved May 17, 2014, from http://www.morvesti.ru/tems/detail. php?ID $=25067$

Furgal, C., \& Prowse, T. D. (2008). Northern Canada. In D. S. Lemmen et al. (Eds.), From impacts to adaptation: Canada in a changing climate (pp. 57-118). Ottawa: Government of Canada.

George, J. (2012). Private yacht visitors to Nunavut create mixed impression in Cambridge Bay: Aussie yacht owner faces liquor charges. Nunatsiaq News. Retrieved June 12, 2014, from http://www.nunatsiaqonline.ca/ stories/article/65674private_yacht_visitors_to_nunavut_ create_mixed_impression_in_cambridge/

Hall, M. C., \& Valentin, A. (2005). Content analysis. In B.W. Ritchie, P. Burns, \& C. Palmer (Eds.), Tourism research methods: Integrating theory with practice (pp. 191-209). Wallingford, UK: CABI Publishing.

Headland, R. (2010). Cruising to the North Pole aboard a nuclear icebreaker. In M. Lück, P. T. Maher, \& E. J. Stewart (Eds.), Cruise tourism in Polar Regions: Promoting environmental and social sustainability? (pp. 25-42). London: Earthscan.

Hodgson, D. (2010). National security and Canada's shipping policy: We can do better. Canadian Navel Review, 6(3), 16-21.

Howell, S. E. L., Tivy, A., Yackel, J. J., \& McCourt, S. (2008). Multi-year sea ice conditions in the Western Canadian Arctic Archipelago section of the Northwest Passage: 1968-2006. Atmosphere-Ocean, 46, 229-242.

Hull, J., \& Milne, S. (2010). Port readiness planning in the Arctic: Building community support. In M. Lück, P. T. Maher, \& E. J. Stewart (Eds.), Cruise tourism in Polar Regions: Promoting environmental and social sustainability? (pp. 181-203). London: Earthscan.

International Maritime Organization. (2014). Shipping in Polar waters. Retrieved August 8, 2014, from http://www. imo.org/MediaCentre/HotTopics/polar/Pages/default.aspx

Johnston, A., Johnston, M. E., Dawson, J., \& Stewart, E. J. (2012). Challenges of changes in Arctic cruise tourism: Perspectives of federal government stakeholders. Journal of Maritime Law and Commerce, 43(3), 335-347.
Johnston, A., Johnston, M. E., Stewart, E. J., Dawson, J., \& Lemelin, R. H. (2012). Perspectives of decision makers and regulators on climate change and adaptation in expedition cruise ship tourism in Nunavut. The Northern Review, 35, 69-85.

Johnston, M., Dawson, J., Stewart, E. J., \& De Souza, E. (2013). Strategies for managing Arctic pleasure craft tourism: A scoping study. A report prepared for Transport Canada, Thunder Bay, Ontario.

Jones, C. S. (1999). Arctic ship tourism: An industry in adolescence. The Northern Raven, 13(1), 28-31.

Kaltenstein, J. (2011). The case for a strong polar code. Retrieved April 3, 2014, from http://libcloud.s3. amazonaws.com/93/94/6/1010/1/Friends_of_the_Earth The_case_for_a_strong_Polar_Code_December_2011.pdf

Lück, M., Maher, P. T., \& Stewart, E. J. (Eds.). (2010). Cruise tourism in Polar Regions: Promoting environmental and social sustainability? London: Earthscan.

Maher, P. T., \& Meade, D. (2008). Cruise tourism in Auyuittuq, Sirmilik, and Quttinirpaaq National Parks: Project technical report (2007 season)—Draft. Iqaluit: Parks Canada.

Main principals of state policy in the Arctic until year 2020. (2009, March 27). Rossiyskaya Gazeta. Retrieved August 12, 2014, from http://www.rg.ru/2009/03/30/arktikaosnovy-dok.html

Marsh, J., \& Staple, S. (1995). Cruise tourism in the Canadian Arctic and its implications. In C. M. Hall \& M. E. Johnston (Eds.), Polar tourism: Tourism and the Arctic and Antarctic regions (pp. 63-72). Chichester, UK: John Wiley and Sons Ltd.

Mistra Arctic Futures. (2014). From resource hinterland to global pleasure periphery? Retrieved August 11, 2014 from http://www.arcticfutures.se/?page_id=59

Quinn, M. (2012, March 5). Russian ship to leave St. John's for the scrap heap. CBC News Newfoundland \& Labrador. Retrieved April 12, 2014, from http://www.cbc.ca/ news/canada/newfoundland-labrador/story/2012/03/04/ nl-orlova-scrapped-304.html

Pashkevich, A., \& Stjernström, O. (2014). Making Russian Arctic accessible for tourists: Analysis of institutional barriers. Polar Geography, 37(2), 137-156.

Pizzolato, L., Howell, S. E. L., Dawson, J., Copland, L., Derkson, C., \& Johnston, M. E. (2013). Climate change adaptation assessment for transportation in Arctic waters (CATAW) scoping study: summary report. A report prepared for Transport Canada, Ottawa, Ontario.

Ringer, G. (2010). Beyond the cruise: Navigating sustainable policy and practice in Alaska's inland passage. In M. Lück, P. T. Maher, \& E. J. Stewart (Eds.), Cruise tourism in Polar Regions: Promoting environmental and social sustainability? (pp. 205-223). London: Earthscan.

Secretariat of the Antarctic Treaty. (2013). Site guidelines for visitors. Retrieved June 12, 2014, from http://www. ats.aq/e/ats_other_siteguidelines.htm

Sheppard, V. (2010). Exploring the ethical standards of Alaska cruise ship tourists and the role they inadvertently play in the unsustainable practices of the cruise 
ship industry. In M. Lück, P. T. Maher, \& E. J. Stewart (Eds.), Cruise tourism in Polar Regions: Promoting environmental and social sustainability? (pp. 75-92). London: Earthscan.

Sivummut Economic Development Strategy Group. (2003). Nunavut Economic Development Strategy: Building a foundation for the future. Retrieved June 3, 2014, from http://www.nunavuteconomicforum.ca/public/files/ strategy/NUNAVUTE.PDF

Smith, L. C., \& Stephenson, S. R. (2013). New trans-Arctic shipping routes navigable by mid-century. Proceedings of the National Academy of Sciences USA, 110(13), E1191-E1195. Retrieved March 18, 2014, from www. pnas.org/cgi/doi/10.1073/pnas.1214212110
Stephenson, S., Brigham L., \& Smith, L. (2014). Marine accessibility along Russia's Northern Sea Route. Polar Geography, 37(2), 111-133.

Stewart, E. J., \& Dawson, J. D. (2011). A matter of good fortune? The grounding of the Clipper Adventurer in the Northwest Passage, Arctic Canada. Arctic, 64(2), 263-267.

Stewart, E. J., Dawson, J. D., \& Draper, D. (2010). Monitoring patterns of cruise tourism across Arctic Canada. In M. Lück, P. T. Maher, \& E. J. Stewart (Eds.), Cruise tourism in Polar Regions: Promoting environmental and social sustainability? (pp. 133-145). London: Earthscan. 